\title{
Pardon Does not Forgive Democracy: Econometrical Analysis of Pardons in Spain ${ }^{1}$
}

\author{
JUAN LUIS JIMÉNEZ ${ }^{2}$ \\ JOSÉ ABREU ${ }^{3}$ \\ Universidad de Las Palmas de Gran Canaria
}

Received: December, 2014

Accepted: May, 2015

\begin{abstract}
The pardon is a legal, although controversial, instrument with a long history that persists in many different judicial systems across the world. The juridical literature often considers it to be a perversion in the separation of powers within the State, and the motivations behind it are always under scrutiny. In this paper we seek to establish whether there are specific factors that affect and determine pardons. Using a database of all pardons granted in Spain between 1995 and 2013, including our own elaborated individual data, the econometrical estimations produce the following conclusions: firstly, Spain's right-wing political party processes pardons faster than that of the left; secondly, and due to public concern, pardons are less frequent near elections; and thirdly, the higher the fine, the faster the pardon. These results show that the pardon is used in a discretionary way and in most cases greatly distorts the separation of powers that should provide the basis of any healthy democratic system.
\end{abstract}

Keywords: Pardons, democracy, politics.

JEL Classification K14, P48, Z18.

\section{Introduction}

The concept of «pardon» has a long history and still persists in many legal systems across the world, such as the United Kingdom, United States, Italy, Korea, etc. Nowadays it is employed by the executive branch of government as an instrument to totally or partially commute fines and/ or prison sentences levied on convicts. Although it can be argued that it enhances fairness and corrects errors within the judicial system (Heise, 2003), it nonetheless remains controversial. As Sarat (2005) states, «pardon» exists in the «barely chartable borderland» of the law.

In the context of Spain this legal element has been used since $1241^{2}$. A more recent key judicial reference is an 1870 Law (18 June, 1870), which regulated pardons granted in Spain. This law was updated in $1988^{4}$.

The use of the pardon has generated controversy relating to political interference in judicial questions ${ }^{5}$. This issue recently arose in Spain, where party politics and even politics 
itself have been brought into question as a result (see surveys of the Center of Sociological Research, CIS). Consequently some authors consider this legal element to be ambiguous and outdated, and are committed to adapting it to a modern legal, social and democratic state (Pérez and Domínguez, 2002; Llorca, 2003; Sánchez-Vera, 2008). Moreover, the most recent update of the law does not require a reason to be given for a pardon or its denial, which has done nothing to enhance transparency.

Academic literature in this field is divided into two parts: the first relates to juridical aspects of the Pardon and Clemency Act; while the second is linked to the statistical or econometric approach to pardons across the world (see section 2). However, as far as we know, no study in Spain or Europe to date has analysed econometrically the factors that condition pardons.

For the reasons given above, the main aim of this article is to clarify whether there are factors that affect pardons granted in Spain. In order to achieve this we employed a database to analyse the 10,205 pardons granted by Spain's central government in the period December 1995-January 2013. We seek to address whether pardons are influenced by variables that are unrelated to justice, equity and/or public utility; which are precisely the factors that should underpin any pardons. In our study we will estimate whether electoral time, importance of offence, political ideology, etc. affect pardons.

Following this introduction, section two reviews the scarce academic literature on this topic. Section three explains the development of the database. Section four details the empirical strategy employed and the estimations model. Finally section five is devoted to results and policy implications. Our results support the disturbing proposition that pardons are used in a discretionary way and in most cases greatly distort the separation of powers that should underpin a healthy democratic system.

\section{Literature review}

The academic literature on this topic has focused on two main questions. The first relates to theoretical-juridical studies (Williston, 1915; Fraile, 2005; Eksterowicz and Roberts, 2006; Barkow, 2009; among others); while the second is based on the statistical (Herrero, 2012; Madrid, 2014; among others) or econometric approach (Whitford and Ochs, 2006; Erler, 2007) to pardons across the world.

The countries that have been studied in the academic literature are the United States (Austin and Hummer, 2000; Whitford and Ochs, 2006, Erler, 2007, among others), Italy (Balassone et al, 2008), Korea (Kwon et al, 2012), and Spain (Pérez and Domínguez, 2002; Llorca, 2003; Doval et al., 2012, etc.).

From a juridical perspective, the pardon has long been controversial (for example, Willinston, 1915, discussed whether a pardon can eliminate the offence). Humbert (1941) exa- 
mined why pardons are granted for the reasons specifically stated in clemency warrants (poverty, old age, «sincerely penitent» or «good conduct», among others). Barkow (2009) argued in his study that the pardon (or clemency ${ }^{6}$ ) has been erratically employed by some presidents, as they have sometimes offered clemency to offenders who pose a low risk and because they wish to reintegrate them into society. Likewise, Baumgartner and Morris (2001) analysed the case of Russia, contending that pardons can be used as a powerful political tool.

In the Spanish case, García (2004) and Fraile (2005) raised some challenging juridical questions about pardons. The authors ask what can legally justify a government waiving a firm and solid conviction imposed by a judge. Specifically, Fraile postulates «(..) are those who pardon not mocking justice and, in doing so, making a mockery of justice?» ${ }^{7}$. For this reason, some authors argue for a legislative change in order to make this Law more transparent and in line with the Constitution (Pérez and Domínguez, 2002; Llorca, 2003; SánchezVera, 2008).

Table 1 summarises a selection of recent papers on the latter type of studies referred to above, (i.e. those relating to the statistical and econometrical analysis of pardons). These analyses have mainly focused on trends in pardons, the variables that influence the granting of pardons and similar descriptive and causal outcomes. 


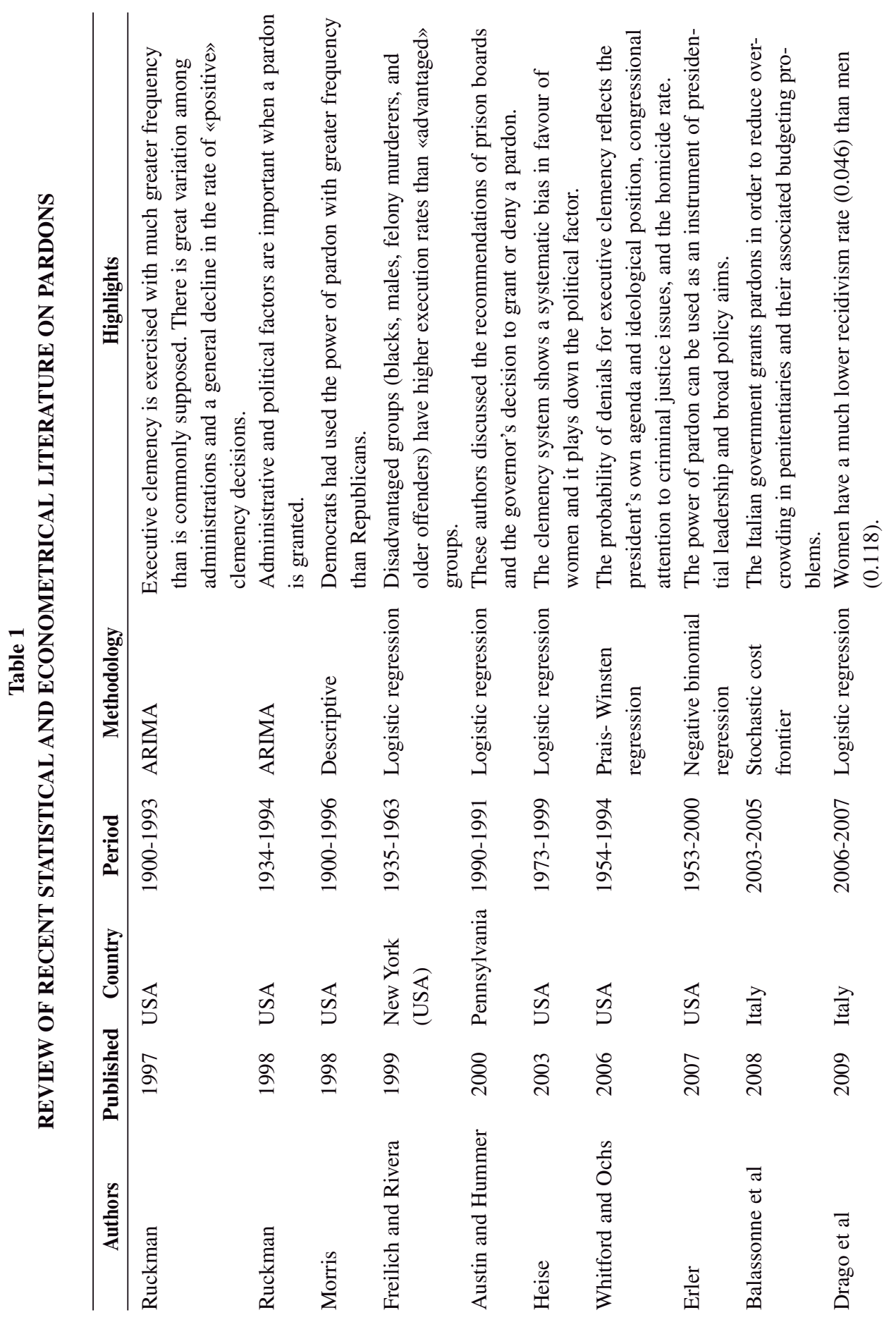




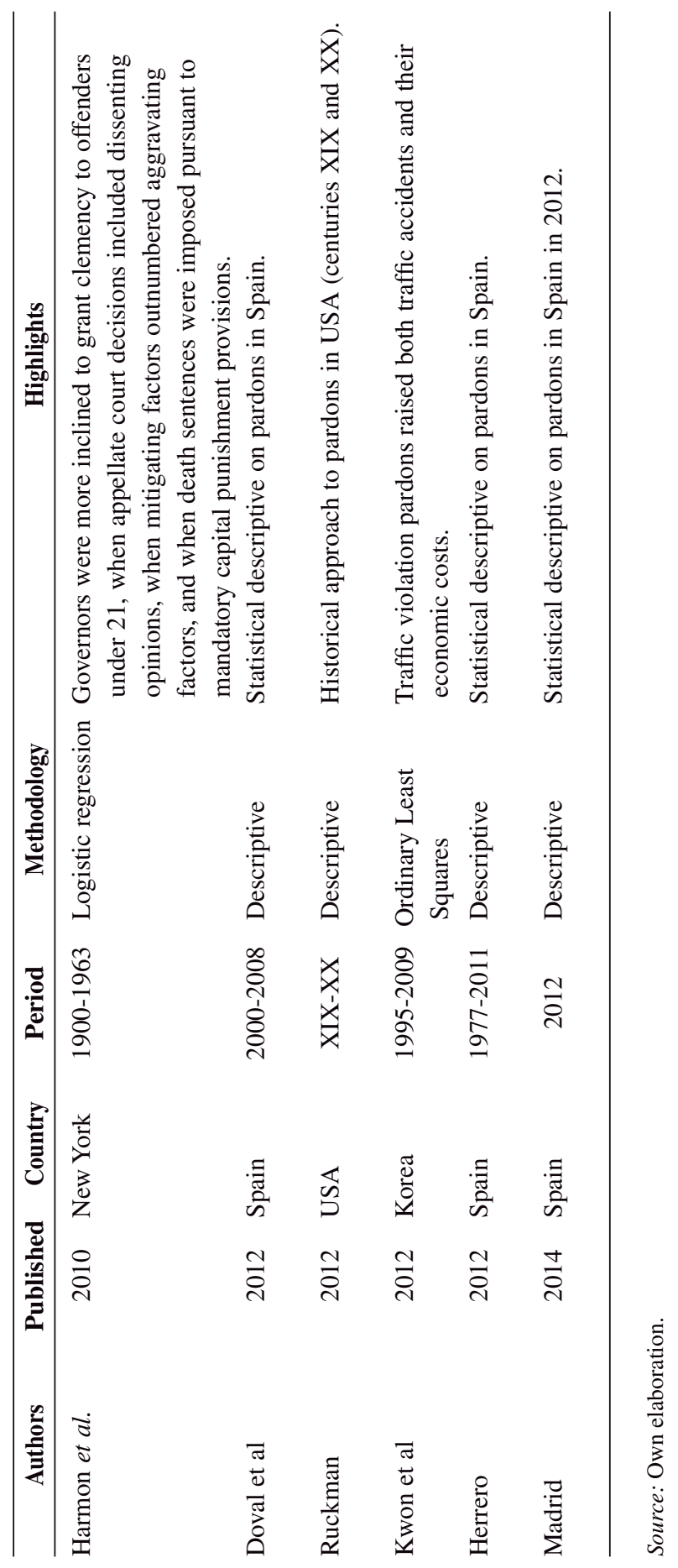


As the above table shows, there are few papers on this topic and the most commonly employed approach to data is descriptive. From these statistical papers we would like to highlight the following findings. Austin and Hummer (2000) studied the variables that might favour clemency in the state of Pennsylvania (USA) using a bivariate analysis and explanatory variables such as gender and type of crime committed. It was found that pardons are more likely when the individual was a woman, a fact that is consistent with the theory of Heise (2003) and Doval et al. (2012) in which convicted women, in relative terms, receive more pardons for family reasons (specifically due to their maternal duties). Moreover, according to the latter study, the offence of theft is more often pardoned because it is considered to be a minor misdemeanour.

Ruckman (1997) conducted an econometric analysis for the United States with an ARIMA model by confirming that the Democratic Party is more likely to grant pardons. Later Ruckman (2011), using a descriptive seasonal analysis, concluded that the presidents of the United States tend to grant pardons in December.

Whitford and Ochs (2006) employed a time series approach for the U. S. in order to illustrate the power that the President and ideology can have in this area. Their results showed that the denial or approval of pardons is sensitive to the ideology of the President, and that the Conservatives are more likely to reject pardons. This result is refuted by Ewal (2002), who argues that the more liberal approach favours reintegration into society to deal with crime, and Borja (2011), who argues that «progressive governments» are more lenient than conservative.

Harmon et al. (2010) examined the factors explaining New York governors' clemency decisions in capital cases. Their statistical analysis drew on a database of 130 cases of commuted sentences (and a control group of 146 cases of execution). As we highlight in table 1, the analysis suggests that governors were more inclined to grant clemency to offenders under 21, when appellate court decisions included dissenting opinions, when mitigating factors outnumbered aggravating factors, and when death sentences were imposed pursuant to mandatory capital punishment provisions. However the authors did not find any evidence that racial, ethnic, or socioeconomic variables were related to clemency decisions.

Erler (2007) analysed whether U. S. presidents used the pardon as an instrument of political leadership based on their own interests. The author found that the power they can exert in this area is tempered by Department of Justice officials and by the actions of previous presidents.

Studies related to Europe, and specifically the Spanish case, are only descriptive. As far as we know, the area under study here has been not been previously analysed in the academic literature. This paper tries to cover aspects influencing clemency that have not been considered in the analysed literature, such as the fine imposed in the sentence, days until the election, or the professional profile of the individual being pardoned (of those that can be identified). So, the contribution of this paper is to identify whether there are factors that influence the 
granting of pardons in the Spanish case. If the pardon was a discretionary act of the judiciary, which is granted for reasons of justice, equity and public utility, and subject to Court reports, then this should not denote an arbitrary act in their concession.

\section{Database}

In order to test the above hypothesis, we have compiled a database that consists of three main sources: the first relates to public data assembled by the CIVIO Foundation relating to all monthly pardons granted by regions in Spain in the period December 1995 to January 2013; the second source is the Spanish Statistical Office (hereafter INE); and finally (and most relevant) our own elaboration of personal data on each pardon granted in Spain. Our database therefore contains two levels of data: provincial and individual. Our empirical strategy will be based on this disaggregation.

Regarding the latter, and using individual data and correlating our information with CIVIO, we conducted a detailed review of various newspaper archives relating to pardons in Spain, in order to find personal and professional information about each of the 10,205 cases. We identified 2,422 individuals, representing $23.7 \%$ of the sample, of which 273 were military (2.67\% of total; $11.3 \%$ of our sample), and 1,184 insumisos (11.6\% of total; $48.9 \%$ of our sample $)^{8}$; the remaining 965 individuals $(9.46 \%$ of total; $39.8 \%$ of our sample), were distributed among the following areas: civil, business, terrorism, trafficking, public office and politics, among others (Table A.1. shows the sample representativeness by year).

The most relevant variables included in the analysis are (the first two variables are dependent in our empirical strategy):

(i) Pardons by month ${ }_{p m t}$ : number of pardons granted by province $p$ in the month $m$ in the $y$ ear $t$. Note that judicial authority at provincial level includes pardons requested, which have then been analysed and passed on to central government, which has the final decision. For this reason, we use provincial level data in the estimation of model 1 (see next section). Source: Own elaboration from CIVIO.

(ii) Days elapsed between sentencing and pardon $_{i}$ : days elapsed from the time a person $i$ is convicted until s/he is pardoned by the government. Source: Own elaboration from CIVIO and State Official Bulletin (BOE).

(iii) Ideology $y_{i m t}$ : binary variable that takes value 1 if the pardon of the person $i$ at month $m$ and year $t$ was granted by a minister of the main right-wing political party in Spain (Partido Popular, the Conservative party). We cannot establish $a$ priori what influence this variable can have on the granting of pardons and time elapsed, but our hypothesis is that the «progressive party» (PSOE, in its Spanish acronym) is more lenient than the conservative, as papers by Ruckman (1997), Morris (1998), Ewal (2002) or Borja (2011) show. Source: Own elaboration. 



gion $j$ at year $t$. We suppose that a positive relationship between this variable and pardons would exist, as Balassone et al. (2008) found for the Italian case. Source: INE.

(v) Jubilee $e_{p m t}$ : binary variable that takes value 1 if the month in which the pardon was granted was December 2000. In this year, central government granted a number of extraordinary pardons in response to requests from Pope John Paul II, the celebration of the Jubilee (known as Xacobeo in Spain), the 22th anniversary of the Spanish Constitution and the approaching end of the millennium. Source: Hearing of Minister of Justice in session 13-12-2000 Commission Justice and Home Affairs; also cited in Doval et al. (2012).

(vi) Trend: yearly trend variable, from 1 to 19 (1995-2013). We seek to control for potential time effects on pardons in Spain.

(vii) Months until the elections: $s_{i}$ this variable indicates the number of months from the month of the pardon to the election month. Our hypothesis is that pardons are not good democratic markers for party politics and they diminish in number before election time. Ruckman (1998) determined that the «election year» does not influence the degree of leniency. On the other hand, Mackuen (1983) argued that numerous domestic and foreign events (e.g. scandals or wars) and presidential decisions affect the popularity of presidents. For example, the author notes that the popularity of President Ford decreased as a result of pardons granted by his predecessor, Richard Nixon. Therefore we seek to test these two controversial outcomes. Source: Own elaboration from CIVIO.

(viii) Crisis $_{i}$ : binary variable that takes value 1 for periods of crisis (in this case, 2008 to 2013). This variable is included in order to control for potential different political behaviour during crises in Spain, when both party politics and politics itself are in social crisis. Source: Own elaboration.

(ix) Coincidence PP (or $\left.P S O E_{j t}\right)$ : binary variable that takes value 1 if party politics at central and regional $(\mathrm{j})$ governments are the same in the year considered $(\mathrm{t})$, in this case, the Conservative party (PP) (or the left-wing party, PSOE). We have considered these variables to test whether between the central and the autonomous levels of government there may be some kind of «partnership» to grant pardons. This practice may be more evident in the case of specific pardons (politicians, celebrities, bankers, etc.). We expect a positive relationship between this variable and the number of pardons. Source: Own elaboration.

(x) Fine $_{i}$ : the amount of the fine imposed on the convict (in euros). If clemency is granted for reasons of justice, equity and public utility or similar, as is expected, there should be no relationship between this variable and the speed with which 
the pardon is granted. However, Schanzenbach and Yaeger (2006) determined that individuals who commit white-collar offences, and who are white and pay a fine, have a lower sentence. In other words, the higher the fine, the lesser the sentence. Source: Own elaboration from CIVIO.

(xi) Population $_{j t}:$ population per region $j$ at year $t$. Source: INE.

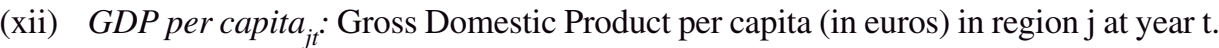
Source: INE.

(xiii) Politician $n_{i}$ : binary variable that takes value 1 if the individual pardoned $i$ held a public office and was involved in politics (eg mayor, councillor, etc.). Source: Own elaboration from sample.

(xiv) Terrorist $_{i}$ : binary variable that takes value 1 if the individual pardoned i was a terrorist, belonged to any terrorist organisation or committed terrorist crimes at the time of the offence. Source. Own elaboration from sample.

(xv) Insumiso ${ }_{i}$ : binary variable that takes value 1 if the individual pardoned $\mathrm{i}$ was an insumiso. Most pardons for insumisos were granted in 1998, so we have to control this year effect in some of our estimations. Source. Own elaboration from sample.

(xvi) Gender: $_{i}$ : binary variable that takes value 1 if the individual pardoned $i$ is a man. As in Austin and Hummer (2000) our hypothesis is that women are pardoned faster than men. Source. Own elaboration from CIVIO.

Descriptive statistics for the database are included in table 2. The average number of monthly pardons by province is 2.8 . The average number of days elapsed from conviction to pardon is 1,178 (three years and three months; although this time period shows great variation). Moreover, both main political parties (the PP and PSOE) have granted a similar number of pardons in this period. The average fine is 150,420 (euros). Males represent $86 \%$ of those pardoned. 
Table 2

DESCRIPTIVE STATISTICS

\begin{tabular}{|c|c|c|c|c|}
\hline Variables & Period/Periodicity & Obs. & Mean (Std. Dev.) & Range \\
\hline Pardons & 1995-2013 / Monthly & 2,948 & $2.8(7.8)$ & {$[1,235]$} \\
\hline $\begin{array}{l}\text { Days between } \\
\text { sentence and pardon }\end{array}$ & 1995-2013 / Individual & 9,933 & $1,178.2(794.1)$ & {$[76,15,438]$} \\
\hline Ideology & 1995-2013 / Individual & 332 & $0.51(-)$ & {$[0,1]$} \\
\hline Convicted by region & 1998-2012 / Yearly & 2,948 & $12,243.8$ (11196.6) & {$[342,46,558]$} \\
\hline Jubilee & 1995-2013 / Individual & 10,204 & $0.13(-)$ & {$[0,1]$} \\
\hline Coincidence PP & 1995-2013 / Individual & 2,948 & $0.19(-)$ & {$[0,1]$} \\
\hline Coincidence PSOE & 1995-2013 / Individual & 2,948 & $0.27(-)$ & {$[0,1]$} \\
\hline Fine & 1995-2013 / Individual & 10,204 & $150,420(4,318,812)$ & {$[0,2.4 \mathrm{e}+08]$} \\
\hline Population (thousands) & 1998-2012 / Yearly & 262 & $2,466.82(2,246.87)$ & {$[64.6,8,299.1]$} \\
\hline GDP per capita & 1998-2012/ Yearly & 262 & $19,554.94(5,089.75)$ & {$[8,536,30,947]$} \\
\hline Politician & 1995-2013 / Individual & 10,205 & $0.0067(-)$ & {$[0,1]$} \\
\hline Terrorist & 1995-2013 / Individual & 10,205 & $0.0024(-)$ & {$[0,1]$} \\
\hline Insumisos & 1995-2013 / Individual & 10,205 & $0.12(-)$ & {$[0,1]$} \\
\hline Number of offences & 1995-2013 / Individual & 9,938 & $1.24(1.5)$ & {$[1,98]$} \\
\hline Gender & 1995-2013 / Individual & 10,205 & $0.86(-)$ & {$[0,1]$} \\
\hline
\end{tabular}

Source: Own elaboration from the CIVIO Foundation and previous sources detailed. Note: Obs.: Observations; Std. Dev.: Standard deviation.

For a descriptive analysis of data, we have included several charts in the Annex. Figure A.1. shows the number of pardons by year, although no trend or cyclical behaviour can be identified from the data. As we previously illustrated, pardons in 1998 and 2000 are significantly higher than other years due to insumisos (in 1998 they represent nearly $51 \%$ of all pardons) and Jubilee year (in December $200076 \%$ of all pardons were granted).

For this reason, figure A.2. includes the numbers of pardons by year without insumisos and pardons granted in December 2000. Here we can identify cyclical behaviour. First, there is an upward trend until 1999, at which time the number of pardons fall. As of 2001, the trend is the same as in figure A.1.

Figure A.3. shows the rate of pardons by conviction. Here, the most significant results are similar to the previous table. Figure A.4 shows the pardons that were granted most frequently by type of offence and political party, as well as other pardons that we considered interesting for their relevance.

We can see that the PP has granted a greater number of pardons for all offences considered (note that the PP has been in government 344 days more than the PSOE in our study) and the 
most pardoned offences are crimes «against public health» and «robbery». Also note that the PP has pardoned 394 more people than the PSOE in individual offences «against road safety» and 16 more for crimes of «terrorism». The latter outcome is due to the pardon granted for 17 convicts of the Catalonian terrorist organisation Terra Lliure; not for ETA's terrorism.

Finally figure A.5. shows relative analysis by electoral period duration, where it should be noted that the PSOE is more likely to grant pardons for offences «against public health» in relative terms.

\section{Empirical strategy and results}

As mentioned, our main aim is to test whether pardons are induced by any variable (time effect, electoral period, political, etc.); or, alternatively, if no statistical pattern can be deduced. The latter would be the expected outcome if a justice, equity and public utility perspective is the origin of pardons (i.e. it should be quite difficult to obtain any statistical pattern).

From this general aim, we have established two detailed questions that lead us to two different empirical strategies. The first question we want to explore is what variables affect monthly pardons by province? Our main hypothesis is that pardons may be affected by both election time, due to the fact that they generate significant public concern; and by some other time effects and trends.

In order to test those questions, our dependent variable is the number of monthly pardons granted by province, and we employ the cluster option in order to reduce deviation among blocks.

Due to the structure of our database count data, a negative binomial regression has been implemented. It is used for modelling count variables, where outcome variables are overdispersed. Stata software contains this specific option (nbreg).

The equation estimated is (equation [1]):

$$
\begin{aligned}
& \text { Monthypardons } \left._{p m t}=\beta_{0}+\beta_{1} \text { Monthsuntilelections }_{p m t}+\beta_{2} \text { (Monthsuntilelections }_{p m t}\right)^{2} \\
& \beta_{3} \text { Convicteds }_{\text {put }}+\beta_{4} \text { CoincidencePP Pmut }_{\text {pur }}+\beta_{5} \text { CoincidencePSOE }_{\text {pmt }}+
\end{aligned}
$$

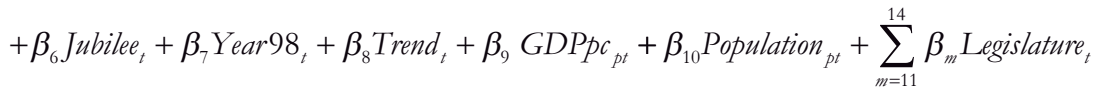

$$
\begin{aligned}
& +\sum_{i=16}^{30} \beta_{i} \text { Year }_{t}+\sum_{j=31}^{43} \beta_{j} \text { Month }_{m}+\varepsilon_{\text {pmt }}
\end{aligned}
$$

Where these monthly estimations $(m)$ are made for all provinces $(p)$ and for each year $(t)$. Binary variables «month» and «year» are included in order to locate potential time effects. 
Despite the fact that this is the general equation, a strong positive correlation exists between population and those convicted (0.82), between crisis and trend $(0.81)$, and between yearly effects and legislature binary variables. The latter relates to all legislative periods in our database ${ }^{8}$. For this reason, we do not include them simultaneously.

Results are shown in table 3. We emphasise that our empirical strategy is to progressively add other control factors, in order to test whether our main variables remain both statistical significance and sign. This has been employed for equation [1] and [2].

Table 3

MONTHLY PARDONS BY PROVINCE. NEGATIVE BINOMIAL REGRESSION

\begin{tabular}{|c|c|c|c|c|}
\hline Explanatory variables & Model 1 & Model 2 & Model 3 & Model 4 \\
\hline Months until elections & $0.03(0.01)^{* * *}$ & $0.03(7 \mathrm{e}-3) * * *$ & $0.03(7 \mathrm{e}-3) * * *$ & $0.006(3 e-3)^{*}$ \\
\hline (Months until elections) $^{2}$ & $-7 e-4(1 e-4)^{* * *}$ & $-8 \mathrm{e}-4(2 \mathrm{e}-4) * * *$ & $-8 \mathrm{e}-4(2 \mathrm{e}-4) * * *$ & $-1 \mathrm{e}-4(8 \mathrm{e}-5)^{* *}$ \\
\hline Convicted per region & & $2 \mathrm{e}-5(5 \mathrm{e}-6)^{* * *}$ & & \\
\hline Trend & $-0.03(0.02)^{* *}$ & $-0.04(0.02)^{* *}$ & $-0.04(0.02)^{* *}$ & $-0.08(0.02)^{* * *}$ \\
\hline Jubilee & $2.43(0.25)^{* * *}$ & $2.42(0.21)^{* * *}$ & $2.46(0.22) * * *$ & $2.80(0.19)^{* * *}$ \\
\hline Year 1998 & & & & $0.64(0.30)^{* *}$ \\
\hline GDP per capita & & $8 \mathrm{e}-5(2 \mathrm{e}-5) * * *$ & $8 \mathrm{e}-5(2 \mathrm{e}-5) * * *$ & $8 \mathrm{e}-5(2 \mathrm{e}-5) * * *$ \\
\hline Population & & & $9 \mathrm{e}-5(3 \mathrm{e}-5)^{* * *}$ & $9 \mathrm{e}-5(3 \mathrm{e}-5)^{* * *}$ \\
\hline Coincidence PP & & $-0.07(0.22)$ & & \\
\hline Coincidence PSOE & & $-0.05(0.12)$ & & \\
\hline Legislature 00-04 (PP) & & & & $-0.43(0.11)^{* * *}$ \\
\hline Legislature 04-08 (PSOE) & & & & $-0.18(0.08)^{* *}$ \\
\hline Legislature 08-11 (PSOE) & & & & $-0.16(0.07)^{* *}$ \\
\hline Legislature 11-15 (13) (PP) & & & & $0.37(0.11)^{* * *}$ \\
\hline Year effects included & Yes & Yes & Yes & No \\
\hline Monthly effects included & Yes & Yes & Yes & No \\
\hline Constant & $0.45(0.26)^{*}$ & $-0.52(0.25)^{* *}$ & $-0.75(0.26)^{* * *}$ & $-0.19(0.22)$ \\
\hline Observations & 3,637 & 3,166 & 3,166 & 3,166 \\
\hline Wald Chi2 & - & $1569.67 * * *$ & $1035.8 * * *$ & $503.11 * * *$ \\
\hline
\end{tabular}

Note: $* * * 1 \%, * * 5 \%, * 10 \%$ significance test. Robust standard errors are shown in brackets.

Previous estimations show all conjointly significance. The most important result in these estimations is the relationship between pardons and «months until elections»: this is positive, and a negative coefficient for squared variable is found. This means that both political parties 
refuse to grant pardons at election time and a cuadratic relationship exists: politicians grant pardons in the middle of their mandate.

However, the hypothesis that «collusive» behaviour may exist when central and regional government are the same party is rejected: coincidence of party political colours shows no statistical significance and they do not explain the number of pardons.

In line with Balassone et al. (2008), another result is that the higher the number of convicted by region, the greater the number of pardons. The same relationship is found for population, which can be explained by higher criminal rates (Glaeser et al., 1996).

Time effects are significant in this regard. Firstly, the number of pardons has decreased over time (the trend is negative). Secondly, despite this previous result, the number of pardons was lower in all legislatures (in respect to the reference legislature, in our case finally 1995 and 1996-2000), except the last one. However we have to note that we have data for only two years of this legislature. And finally, when we include monthly effects, we have not found any significant outcome.

After showing that certain specific factors affect the timing of pardons in Spain, the second question we are seeking to respond to is based on an individual analysis. Using economic, political and personal characteristic variables, our aim is to determine whether there is any factor that influences days elapsed from sentence to pardon. Therefore the question we seek to respond to is: are there specific factors that determine the speed of pardon concession? The hypothesis is that no factor should affect this period if pardons are granted for reasons of justice, equity and public utility alone.

In order to meet this objective, we have considered 9,932 pardons ${ }^{10}$. Moreover, we also make estimations using the 2,422 pardoned individuals about whom we have obtained personal information (see previous section). The equation has been estimated by and Ordinary Least Squares (OLS) method, and it is (equation [2]):

$$
\begin{aligned}
& \ln \left(\text { Dayselapsed }_{i t}=\beta_{0}+\beta_{1} \ln \left(\text { Fine }_{i}+\beta_{2} \text { Ideology }_{i}+\beta_{3} \text { Politician }_{i}+\beta_{4} \text { Terrorist }_{i}+\right.\right. \\
& +\beta_{5} \text { Insumiso }_{i}+\beta_{6} \text { Gender }_{i}+\beta_{7} \text { Jubilee }_{t}+\beta_{8} \text { Crisis }_{t}+\beta_{9} \ln \left(\text { NumberOffences }_{i}+\right. \\
& +\sum_{d=10}^{31} \beta_{d} \text { Typeoffence }_{i}+\sum_{i=32}^{35} \beta_{i} \text { Legislature }_{t}+\varepsilon_{i t}
\end{aligned}
$$

The dependent variable is the logarithmic of the days elapsed, and the two continous covariates included are in logarithmics. In model 4 we control for every type of possible offence (typeoffence) by including 21 binary variables (the most important one, «against public health» was used as the reference covariate in this case). Results are detailed in table 4. 


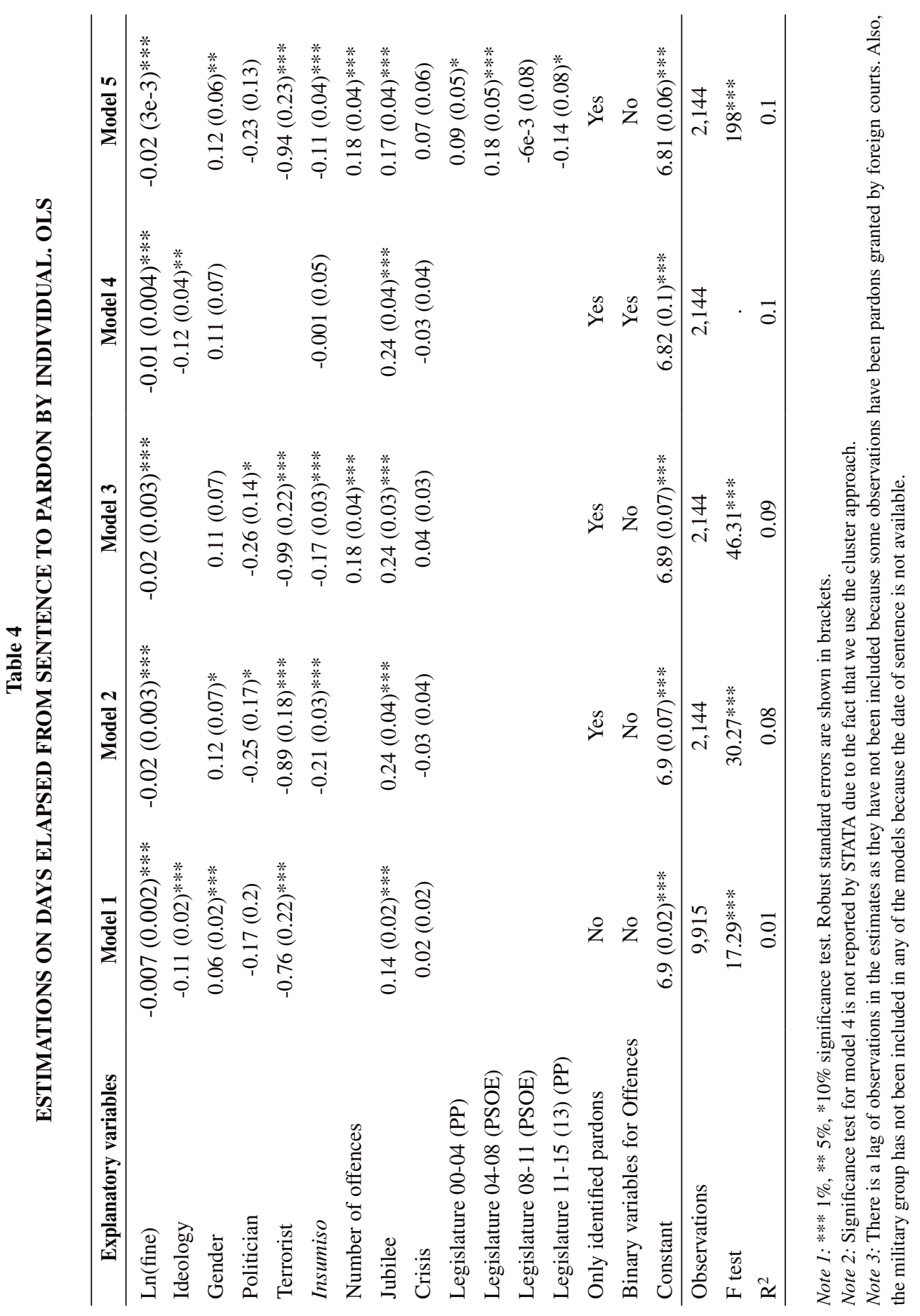


Estimations in table 4 show that all conjointly significance and goodness of fit is lower than 0.1. Nevertheless, several important points arise from these data. The most noticeable is that there is a negative relationship between the dependent variable (days elapsed) and the level of fine imposed on the convict. In fact, a 1 per cent increase in the amount of fine decreases the number of days elapsed by around 0.02 . So, this means that the higher the fine, the faster the pardon concession. If a pardon were granted for reasons of justice, equity and public utility, the fine should not be a relevant factor. The fine is an indicator of the seriousness of the offence or economic power of the convict. However, this result is consistent with Schanzenbach and Yaeger (2006), who showed that the payment of a fine reduces the sentence.

Regarding ideology, the negative coefficient of this variable implies that pardons granted by the conservative party are processed faster than those by the left-wing party. Regarding the profile of those pardoned: politicians, terrorists and insumisos are pardoned faster than those who committed other crimes.

Pardons granted to men are slower than those to women (note that close to $89 \%$ of convicts in Spain are men). This outcome is supported by the academic literature, as we have previously detailed (Heise, 2003; Doval et al., 2012; Herrero, 2012). In 2000 more people with longer sentences were pardoned than average, although the crisis was found to have no influence on the days elapsed between sentence and pardon. Finally, pardons in legislatures 00-04 and 04-08 were processed more slowly than the reference legislature, but the last legislature shows that pardons were granted faster.

In short, the results show that pardons have a significant temporal and ideological bias, at least in this study, and that there are other factors that have nothing to do with justice, equity and/or public utility that are influencing the pardons granted. Therefore, these results support the disturbing idea that the pardon is used in a discretionary way and in most cases greatly distorts the separation of powers that should underpin a healthy democratic system.

\section{Conclusions}

The pardon is a legal instrument used by the executive branch of the government in order to totally or partially commute the fines and/or prison sentences levied on convicts. Although it can be argued that it enhances fairness and correct errors of the judicial system (Heise, 2003), it is a controversial element that persists in many different legal systems across the world (United Kingdom, United States, Italy, Korea, etc.).

This issue has recently been under the spotlight in Spain, where party politics and also occasionally politics itself have been brought into question by certain sections of society. As a result, some authors consider this element of the law to be ambiguous and outdated, and are committed to adapting it to a modern social and democratic state of law (Pérez and Domínguez, 2002; Llorca, 2003; Sánchez-Vera, 2008). Moreover, the most recent update of the law does not require a reason to be given for a pardon or its denial. 
In this paper we have tried to shed some light on the factors that affect and determine pardons in Spain. In order to achieve that we have built a database for the period 1995-2013, which consists of three main sources: public data compiled by the CIVIO Foundation (consisting of all monthly pardons granted by Spanish regions in the period); the Spanish Statistical Office; and finally (and most relevant) our own elaboration of specific data on each pardon granted in Spain.

Our econometrical approach yielded several key conclusions. The first is that election periods are not a good time for pardons. In fact, politicians tend to grant most pardons halfway through their mandates, probably due to the public concern that pardons generate.

The second result we highlight is that there is a negative relationship between days elapsed from sentence to pardon and the amount the individual is fined. In fact, a 1 per cent increase in the amount of the fine decreases the number of days elapsed to around 0.02 . Therefore, this implies that the higher the fine (and it is therefore supposed the greater the offence), the faster the pardon is conceded. Finally, the Conservative party is more prone to process pardons faster than the left-wing party.

In summary, the results show that pardons are ideologically biased in Spain, and that there are other factors alien to justice, equity and/or public utility that are influencing the granting of pardons. Therefore, these results support the disturbing conclusion that the pardon is employed in a discretionary way and in most cases greatly distorts the separation of powers that should underpin a healthy democratic system.

\section{Notes}

1. The authors are thankful for comments by Andreu Arenas, Joaquín Artés, Javier Campos, Aday Hernández, Jordi Perdiguero, Socorro Puy, Alejandro Rodríguez, Pablo Simón, participants at the XXII Encuentro de Economía Pública (Santander) and two anonymous referees. We especially thank Eva Belmonte and Fundación CIVIO for providing us with the original database on judicial pardons in Spain. Juan Luis Jiménez acknowledges financial support by the Spanish Ministry of Innovation through grant CSO2013- 40870-R and by Instituto de Estudios Fiscales (Ministerio de Hacienda y Administraciones Públicas), through grant I. E. F. 154/2014. All errors are ours.

2. Corresponding author: Universidad de Las Palmas de Gran Canaria. Departamento de Análisis Económico Aplicado. Facultad de Economía, Empresa y Turismo. Despacho D. 2-12. Campus de Tafira. 35017. Las Palmas. juanluis.jimenez@ulpgc.es; tel: +34 928458191.

3. Universidad de Las Palmas de Gran Canaria. jose.abreu101@alu.ulpgc.es.

4. Liber Iudiciorum, edicted by Recesvinto in 654, and adopted by Fernando III.

5. Ley 1/1988, 14 enero, por la que se modifica la Ley 18 junio 1870, estableciendo reglas para el ejercicio de la gracia de indulto. See Herrero (2012) for a juridical and historical approach to the pardon system in Spain.

6. See for example the media dissemination of «Caso Marey» (Cobo, 2003), the pardon for judge Gómez de Liaño (Pérez and Domínguez, 2002) or banker Alfredo Sáenz (Madrid, 2014).

7. These terms are used interchangably in this text.

8. Fraile (2005). This statement was made in the context of a change to the Spanish Law in 1988.

9. An insumiso is a man who refuses to do military or community service. Many insumisos argue that the discrimination against men inherent in the system is unconstitutional and the exploitation, as they see it, of unpaid labour is unlawful. Penalties for insumisión (refusal to do either form of service) can be severe, and may include prison sentences (Collins dictionary). 
10. The recent national legislatures in Spain were: 1992-1996, 1996-2000, 2000-2004, 2004-2008, 2008-2011 and 2011-2015.

11. The sample used here does not include soldiers, because it has been impossible to get information regarding the date of sentence.

\section{References}

Austin, T. L., Hummer, D. (2000), «The Effect of Legal and Extra-Legal Variables on the Recommending and Granting of a Pardon», Law and Policy, 22 (1), January, 49-65.

Balassone, F., Camilletti, M., Grembi, V., Zanardi, A. (2008), «Evaluating the Efficiency of the Italian Penitentiary System». ECONPUBBLICA. Centre for Research on the Public Sector. Università Commerciale Luigi Bocconi.

Barkow, R. E. (2009), «The politics of forgiveness: reconceptualizing clemency. Federal Sentencing Reporter», 21(3), ABA Roundtable on «Second Look» sentencing reforms, 153-159.

Baumgartner, J., Morris, M. (2001), «Presidential Power Unbound. A comparative Look at Presidential Pardon Power», Politics \& Policy, 29(2).

Borja, E. (2011), Curso de Política Criminal. Valencia. Tirant lo Blanch.

Cobo, M. (2003), Caso Marey. Dykinson.

Doval, A., Blanco, I., Fernández-Pacheco, C., Viana, C., Sandoval, J. C. (2012), «Las concesiones de indultos en España (2000-2008)», Revista Española de Investigación Criminológica, Universidad de Alicante, Artículo 5, 9 (2011).

Drago, F., Galbiati, R., Vertova, P. (2009), «The Deterrent Effects of Prison: Evidence from a Natural Experiment», Journal of Political Economy, 117(2), 257-280.

Eksterowicz, A. and Roberts, R. N. (2006), «The specter of presidential pardon», White house Studies Compendium, 6, 319-331.

Erler, H. A. (2007), «Executive clemency or bureaucratic discretion? Two models of the pardon process», Presidential Studies Quarterly, 37(3), 427-448.

Ewal, A. C. (2002), «Civil Death: The Ideological Paradox of Criminal Disenfranchisement Law in the United States», Wisconsin Law Review, 9, 1045-1137.

Fraile, M. (2005), [Recensión del libro El indulto. Un análisis jurídico-constitucional, de Dña. R. García Mahamut (Eds.)], Revista Teoría y Realidad Constitucional, 16, 2. ${ }^{\circ}$ semestre 2005, 507-511.

Freilich, J. D., Rivera, C. J. (1999), «Mercy, death, and politics: an analysis of executions and commutations in New York State, 1935-1963», American Journal of Criminal Justice, 2481, 15-29.

García, R. (2004), El indulto. Un análisis jurídico-constitucional, Madrid/Barcelona, Marcial Pons, 2004.

Glaeser, E. L., Sacerdote, B., Sheinkman, J. A., (1996), «Crime and Social Interactions», Quarterly Journal of Economics, 507-548.

Harmon, T. R., Acker, J. R. and Rivera, C. (2010), «The power to be lenient: examining New York Governors» capital case clemency decisions». Justice Quarterly, 27(5), 742-764. 
Heise, M. (2003), «Mercy by the numbers: an empirical analysis of clemency and its structure». Virginia Law Review 89(2), 239-310.

Herrero, I. (2012), El derecho de gracia: indultos (Tesis Doctoral), Madrid, Universidad Nacional de Educación a Distancia.

Humbert, W. H. (1941), «The Pardoning Power». Washington, D. C. American Council on Public Affairs.

Kwon, Y., Han, S. H., Nam, C. (2012), «Estimating the costs of political populism: traffic violations pardons in Korea». Transportation Research Part A, 46, 1449-1457.

Llorca, J. (2003), La Ley del indulto (Comentarios, Jurisprudencia, Formularios y notas para su refor$m a$ ). Valencia. Tirant lo Blanch.

Mackuen, M. (1983), «Political Drama, Economic Conditions, and the Dynamics of Presidential Popularity». American Journal of Political Science, 27, 165-192.

Madrid, A. (2014), «El indulto como excepción. Análisis de los indultos concedidos por el Gobierno español durante 2012», Revista Crítica Penal y Poder, OSPDH, Universidad de Barcelona, 6, marzo, 110-133.

Morris, M. (1998), «The overlooked relevance of the pardon power», in Presidential Frontiers: underexplored issues in White House politics, Barilleaux, R. J., 79.

Pérez, J. L., Domínguez, F. (2002), «El indulto como acto del Gobierno: una perspectiva constitucional (Especial análisis del «caso Liaño»)». Revista de Derecho Político, 53, 25-73.

Ruckman Jr., P. S. (1997), «Executive Clemency in the United States: Origins, Development, and Analysis (1900-1993)». Presidential Studies Quarterly, 27, 251-271.

Ruckman Jr., P. S. (1998), «President-centered and Presidency centered Explanations of Federal Executive Clemency Policy». Presented at the Annual Meeting of the Southern Political Science Association: Atlanta, Georgia.

Ruckman Jr., P. S. (2011), «Seasonal Clemency Revisited: An Empirical Analysis». White House Studies, 11, 21-38.

Ruckman Jr., P. S. (2012), «The study of mercy: what political scientists know (and don't know) about the pardon power», U. St. Thomas L. J., 9, 783-831.

Sánchez-Vera, J. (2008), «Una lectura crítica de la Ley del indulto», InDret: Revista para el análisis del Derecho, 2/2008, abril, 1-32.

Sarat, A. (2005), «At the boundaries of Law: Executive clemency, sovereign prerogative, and the dilemma of American Legality», American Quarterly, 57, 611-618.

Schanzenbach, M., Yaeger, M. L. (2006), «Prison Time, Fines and Federal White-Collar Criminals: The Anatomy of a Racial Disparity», The Journal of Criminal Law and Criminology, 96(2), 757-793.

Whitford, A. B., Ochs, H. L. (2006), «The Political Roots of Executive Clemency», American Politics Research, 34, 6, November, 825-846.

Williston, S. (1915), «Does a Pardon Blot out Guilt?» Harvard Law Review, 28 (7), May, 647-663. 


\section{Resumen}

Los indultos son un instrumento legal, aunque genera controversias, con una dilatada historia que persiste un diferentes sistemas judiciales en el mundo. La literatura académica la considera como una perversión en la separación de poderes dentro del Estado, y sus motivaciones están bajo escrutinio. En este trabajo perseguimos establecer si existen factores específicos que afectan a la concesión de los indultos. A partir de una base de datos que contiene todos los indultos concedidos en España en 1995 y 2013, así como información de elaboración propia, las estimaciones econométricas concluyen que: en primer lugar, el Partido Popular gestiona con mayor celeridad los indultos que el Partido Socialista; en segundo lugar y motivado por la opinión pública, los indultos son menos frecuentes en época de elecciones; y en tercer lugar, cuanto mayor sea la multa impuesta, más rápido es la concesión del indulto. Estos resultados muestran un uso discrecional de los indultos, apoyando la tesis acerca de la distorsión que genera en la separación de poderes que debería ser la base de cualquier sistema democrático saludable.

Palabras clave: Indultos, democracia, política.

Clasificación JEL: K14, P48, Z18.

ANNEX

Table A.1

SAMPLE REPRESENTATIVENESS

\begin{tabular}{cccc}
\hline Year & Total pardons & Sample pardons & Percentage sample \\
\hline 1995 & 47 & 9 & 19.1 \\
1996 & 530 & 87 & 16.4 \\
1997 & 738 & 54 & 7.3 \\
1998 & 1.582 & 865 & 54.7 \\
1999 & 741 & 41 & 5.5 \\
2000 & 1744 & 514 & 29.5 \\
2001 & 245 & 28 & 11.4 \\
2002 & 253 & 30 & 11.9 \\
2003 & 299 & 58 & 19.4 \\
2004 & 320 & 60 & 18.7 \\
2005 & 457 & 47 & 10.3 \\
2006 & 517 & 86 & 16.6 \\
2007 & 543 & 83 & 15.3 \\
2008 & 442 & 86 & 19.5 \\
2009 & 438 & 72 & 16.4 \\
2010 & 404 & 57 & 14.1 \\
2011 & 359 & 102 & 28.4 \\
2012 & 534 & 142 & 26.6 \\
2013 & 12 & 1 & 8.3 \\
\hline
\end{tabular}

Source: Own elaboration and the CIVIO Foundation.

Note: Data for 1995 and 2013 only contains December and January, respectively. 




Figure A.1. Pardons by year

Source: Own elaboration from the data provided by the Civio Foundation. Note: 1995 and 2013 data only include December and January data respectively.

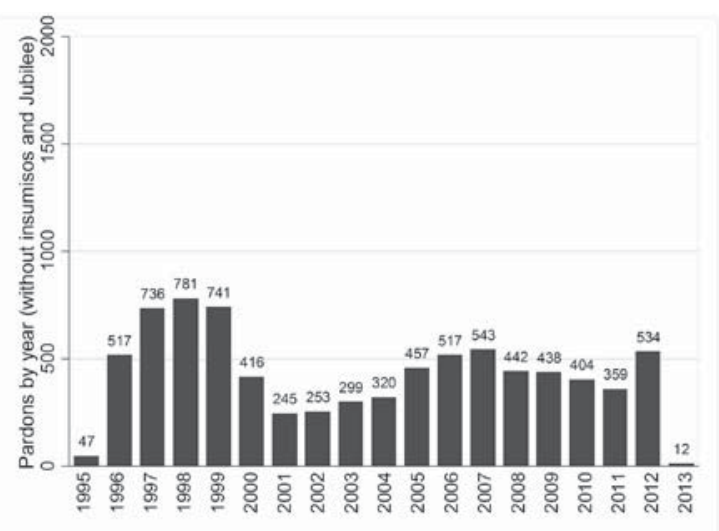

Figure A.2. Pardons by year (without insumisos and Jubilee)

Source: Own elaboration from the data provided by the Civio Foundation. Note: 1995 and 2013 data only include December and January data respectively. 


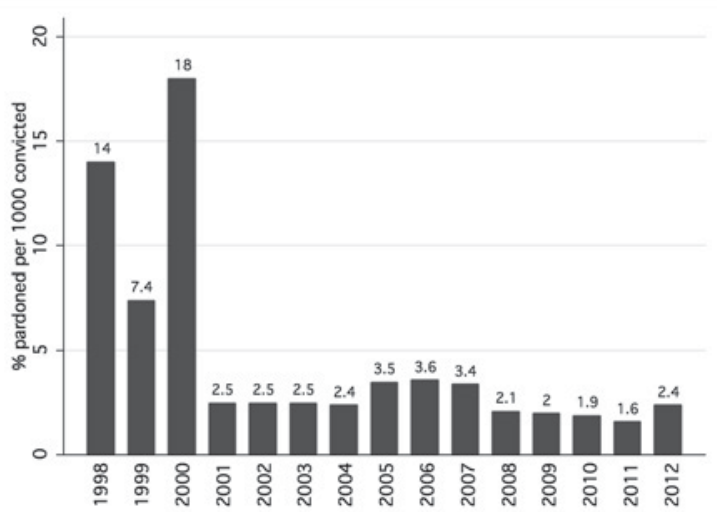

Figure A.3. Pardoned rate

Source: Own elaboration from INE. Note: No data available for those convicted before 1998. 2013 data only include January data.

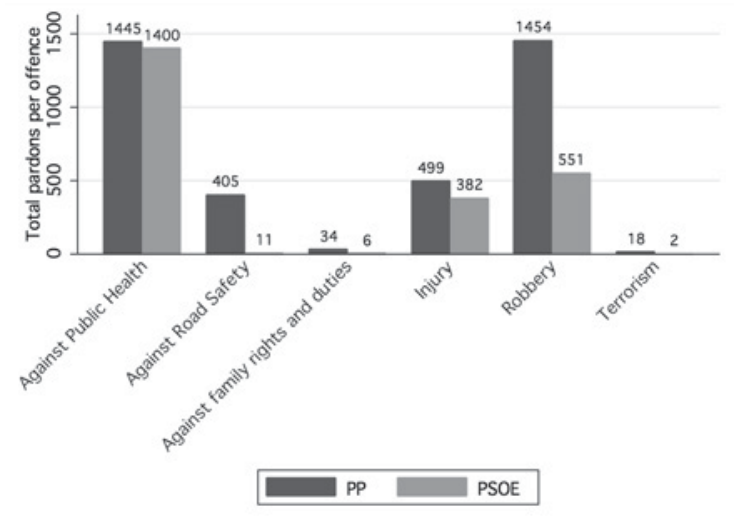

Figure A.4. Total pardons per offence and party

Source: Own elaboration from the data provided by the Civio Foundation. Note: In our sample, the PP has been in government 3,298 days, while the PSOE has held office for 2,954 days. 


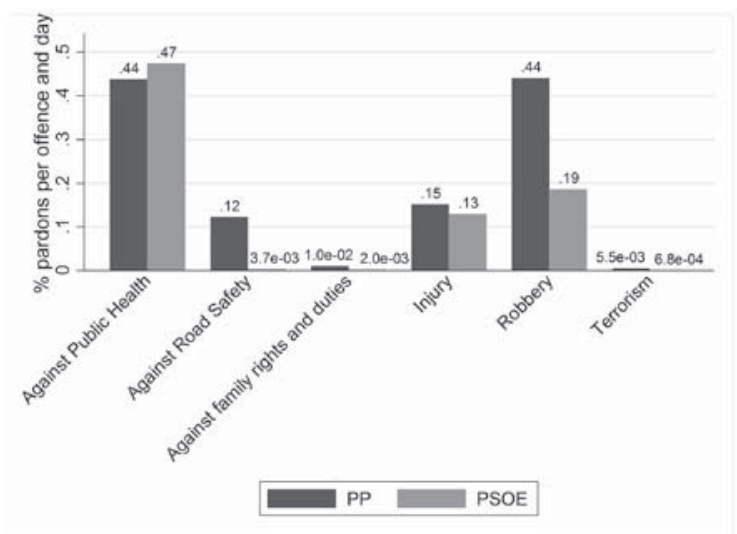

Figure A.5. \% pardons per offence and day

Source: Own elaboration from the data provided by the Civio Foundation. Note: In our sample, the PP has been in government 3,298 days, while the PSOE has held office for 2,954 days. 